\title{
EVALUASI PENGEMBANGAN POTENSI "ANCIENT TRACK ONE" DENGAN MODEL CIPP DI DESA WISATA BEDULU DAN DESA BURUAN KABUPATEN GIANYAR
}

\author{
I Gede Anom Sastrawan', Syamsul Alam Paturusi², \\ I Nyoman Sukma Arida ${ }^{3}$ \\ 1,2,3 Universitas Udayana \\ Email: anom_sastrawan@unud.ac.id
}

\begin{abstract}
The study aims to evaluate the quality improvement activities in order to appeal tracking tours in Gianyar regency, Bali. The concept used in this study is the evaluation of the concept, the concept of tourism potential and attractions as well as the concept of rural tourism, village tourism concept, the concept of alternative tourism, archaeological tourism concept and the concept of alternative tourism. The theory is used to analyze this study is the evaluation theory, the theory of sustainable tourism development and tourism destination development theory are analyzed with models CIPP (Context, Input, Process, Product). Moreover, the constraints faced in the implementation of development Ancient Tracking One at the Tourism Village Bedulu and Villages Buruan. Associated with the constraints in the development of Ancient Track One can be seen from has not been established as a legal organization as a manager of a tourist attraction. Suggestions put forward in this study, namely: commitment required for the implementation of tourism activities Ancient Track One, with no synchronization between the aspects of context, input, process and product development of tourism in Ancient Track One, as a tourist attraction based on historical and archaeological heritage, tourist areas need to be set right brand that can distinguish between this region with other regions.
\end{abstract}

Keywords: development evaluation, ancient track one, alternative tourism, Buruan Village Gianyar.

\footnotetext{
Abstrak

Penelitian ini dilakukan untuk mengevaluasi kegiatan yang dilakukan dalam rangka pembenahan kualitas daya tarik wisata yang ada di Kabupaten Gianyar, Bali. Konsep yang digunakan dalam penelitian ini yaitu konsep evaluasi, konsep potensi wisata
} 
dan daya tarik wisata serta konsep wisata alternatif. Teori yang digunakan untuk menjawab dan menganalisis permasalahan dalam penelitian ini yaitu teori-teori yang dianggap relevan diantaranya teori evaluasi, teori pembangunan pariwisata berkelanjutan dan teori pengembangan destinasi pariwisata serta dianalisis dengan model CIPP (Contexs, Input, Process, Product). Dalam upaya pengembangannya, aktivitas trakking Ancient Trek One memiliki penyimpangan atau ketidaksinkron aspek dalam rangka pengembangan. Untuk unsur partisipasi masyarakat relatif baik karena tingginya animo masyarakat untuk mengembangkan pariwisata di daerah ini baik dari sisi Desa Bedulu maupun Desa Buruan. Sebagai sebuah daya tarik wisata berbasis peninggalan sejarah dan arkeologi, perlu ditetapkan brand kawasan wisata yang tepat yang dapat membedakan antara kawasan ini dengan kawasan yang lain.

Kata kunci: evaluasi pembangunan, ancient track one, pariwisata alternatif, Desa Buruan Gianyar.

\section{Pendahuluan}

Menikmati daya tarik wisata heritage di daerah Gianyar, Bali, seperti Goa Gajah, Relief Yeh Pulu dan Pura Bukit Dharma Durga Kutri secara selintas (sight seeing) memang sudah biasa bagi wisatawan domestik maupun mancanegara. Namun menikmati wisata heritage melalui aktifitas tracking, belum banyak dijumpai. Salah satu kegiatan wisata yang dapat dinikmati oleh wisatawan yang menyukai kegiatan alam dan situs budaya di Desa Wisata Bedulu dan Desa Buruan adalah mengembangkan daya tarik wisata Tracking. Evaluasi tersebut dilakukan dalam rangka pembenahan kualitas daya tarik wisata yang ada di Kabupaten Gianyar.

Artikel ini bertujuan untuk mengevaluasi bagaimanakah pelaksanaan pengembangan Ancient Track One di Desa Wisata Bedulu dan Desa Buruan sebagai daya tarik wisata alternatif di Kabupaten Gianyar ditinjau dari aspek konteks, input, proses dan produk sebagai daya tarik wisata

\section{Teori dan Model Penelitian}

Arikel ini mengaplikasikan konsep potensi wisata dan daya tarik wisata, desa wisata, daya tarik wisata alternatif, wisata situs budaya (heritage tourism), dan pariwisata berbasis masyarakat (community based tourism) dengan menguji teori Evaluasi, Pembangunan Pariwisata Berkelanjutan dan Pengembangan Destinasi Pariwisata dalam menganalisis pengembangan potensi Ancient Track One di Desa Wisata Bedulu dan Desa Buruan.

Model CIPP (Context, Input, Process, Product) yang dirancang oleh 
Stufflebeam (dalam Zhang, dkk, 2011:61) dan dipadukan dengan analisis deskriptif kualitatif yakni analisis data yang berusaha mendeskripsikan atau menggambarkan fenomena atau hubungan antara fenomena yang diteliti dengan cara sistematis, faktual dan akurat menurut Kusmayadi dan Sugiarto (2000). Parameter penilaian yang diuraikan dalam artikel ini diambil dari penafsiran penulis terhadap implementasi dari teori Evaluasi model CIPP (Context, Input, Process, Dan Product), di mana parameter penilaian tersebut dijelaskan dalam Tabel 1.1.

Tabel 1.1 Aspek dan Parameter Penilaian Evaluasi Pengembangan dengan Model CIPP

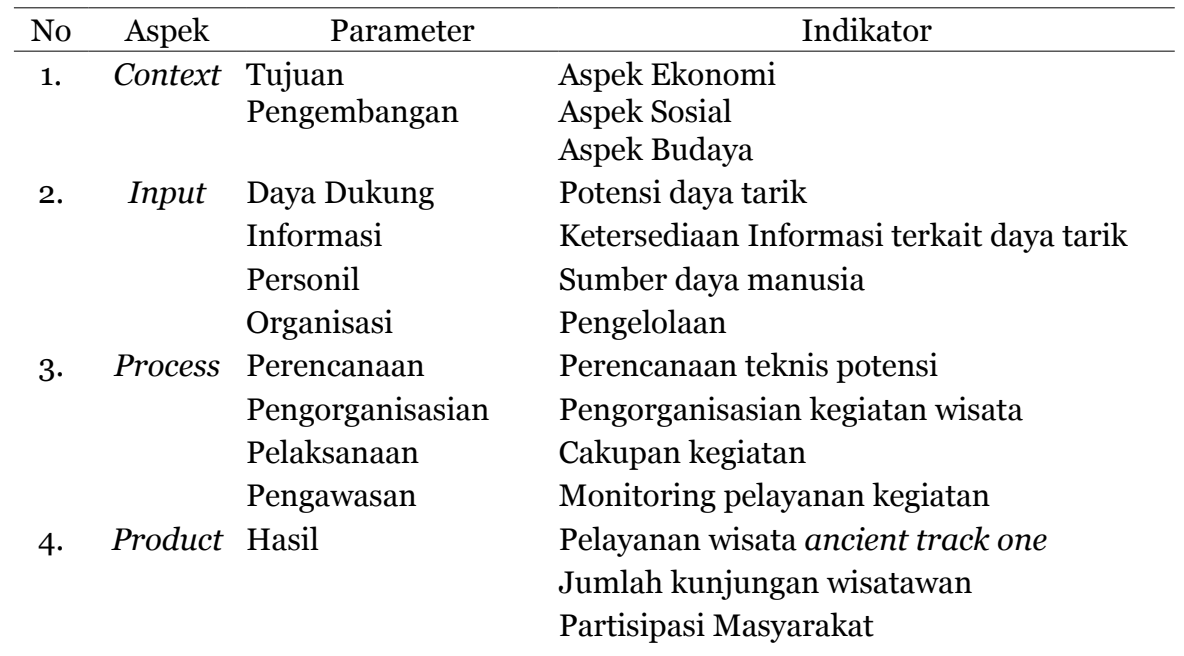

Sumber: Hasil Penelitian, 2016

\section{Gambaran Umum Lokasi}

Gambaran umum ini menguraikan tentang sejarah singkat Desa Wisata Bedulu dan Desa Buruan terkait dengan letak, luas, dan kondisi geografis di dua (2) lokasi daerah pada artikel ini dan kondisi demografi masyarakatnya, serta gambaran umum Desa Wisata Bedulu dan Desa Buruan. Uraian tentang gambaran umum daerah pada artikel ini sebagai berikut:

\subsection{Desa Wisata Bedulu}

Secara etimologi nama Bedulu sebagai nama sebuah desa seperti sekarang ini diperkirakan berasal dari kata Bedahulu seperti yang terdapat dalam kitab Negara Kertagama yang ditulis oleh Empu Prapanca pada tahun 1365 Masehi. Pada pupuh XIV bait nomor tiga (3) antara lain disebutkan bahwa Negara bawahan di sebelah timur Jawa dan Bali dengan Negara yang penting Bedahulu dan Lwa Gajah (Graff \& Pigeaud 1985, dalam Profil Desa Wisata Bedulu, 2013). Sebagai desa kuno dan desa wisata, Bedulu telah mewariskan tinggalan-tinggalan arkeologi yang mengandung nilai budaya, 


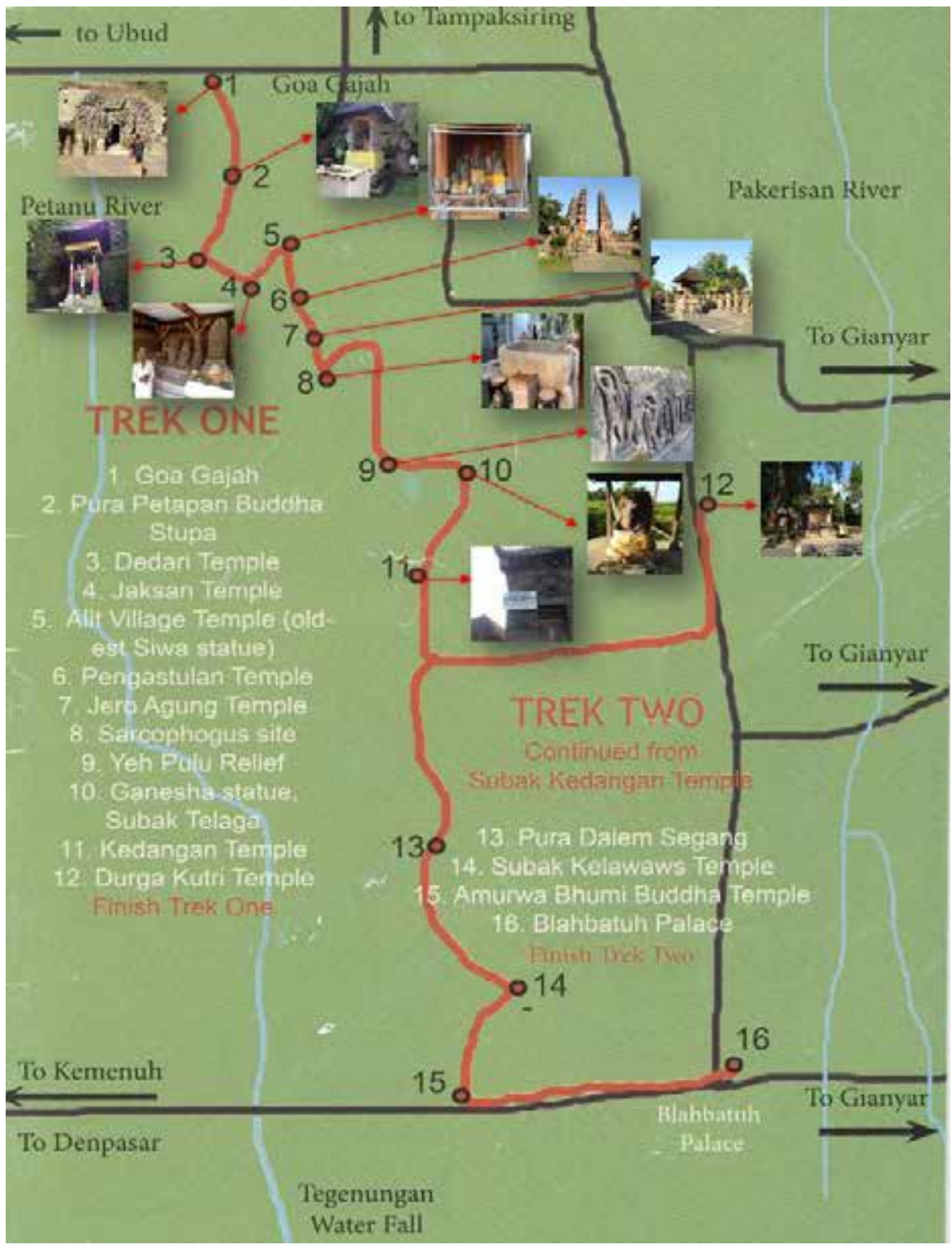

Foto 1. Jalur Ancient Track One.

sosial, ekonomi, pendidikan dan juga teknologi. Kata Badahulu terdiri dari atas kata bada yang berarti tempat dan hulu yang berarti pemimpin, penghulu atau raja.

Desa Wisata Bedulu merupakan salah satu bagian dari wilayah kecamatan Blahbatuh, Kabupaten Gianyar, yang memiliki luas wilayah 401,39 Ha dengan letak koordinat $8^{\circ} 31.4$ Lintang Selatan dan $115^{\circ}$ 17.56,6 Bujur Timur terletak sekitar 150 meter dari permukaan laut. Keberadaan Desa Wisata Bedulu sepertinya berada ditengah-tengah pulau Bali dan sangat dekat sehingga 
mudah dicapai dari semua arah penjuru, baik dari kota Provinsi Bali yaitu Kota Denpasar yang berjarak $25 \mathrm{~km}$ dan dapat ditempuh dalam kurun waktu sekitar 35 menit sedangkan jarak ke kota kabupaten yaitu Kota Gianyar hanya berjarak $5 \mathrm{~km}$ dan dapat ditempuh dalam kurun waktu 10 menit.

\subsection{Desa Buruan}

Nama Desa Buruan itu mengambil nama Candi tersebut yaitu "Bhur Wan" yang berasal dari bahasa sansekerta Bhur yang artinya tanah atau bumi dan Wan berarti mulia atau suci. Jadi Bhur Wan berarti tanah yang suci atau mulia. Dalam perkembangannya terjadi perubahan pengucapan yang disesuaikan dengan kemampuan lafal lidah Bali. Maka nama Bhur Wan berubah menjadi "Buruan”. (RPJM Desa Buruan, 2016).

Secara Geografis Desa Buruan, Kecamatan Blahbatuh, Kabupaten Gianyar merupakan daerah landai dengan ketinggian 30 meter diatas permukaan laut, curah hujan relatif basah dengan batas wilayah administratif adalah sebelah Utara berbatasan dengan Desa Wisata Bedulu, sebelah Timur berbatasan dengan Kelurahan Bitera, sebelah Selatan berbatasan dengan Desa Blahbatuh, sebelah Barat berbatasan dengan Desa Kemenuh.

\section{Analisis Context, Input, Process, Product Ancient Track One}

Pelaksanaan kegiatan wisata tracking Ancient Track One di Desa Wisata Buruan dalam penelitian ini dianalisis dengan merujuk pada teori evaluasi CIPP (Context, Input, Process, Product) yang dikeluarkan oleh Zhang (2011:69) dengan masing-masing indikator dan hasil empirik dilapangan dan akan dijelaskan pada Tabel 4.1 sebagai berikut:

\subsection{Aspek Context Pengembangan Ancient Track One}

Mengacu kepada Dokumen Penataan dan Pengembangan Kawasan Wisata Goa Gajah dan Yeh Pulu, Sugiana (2015:6) menjelaskan konsep penataan yang dikembangkan di Ancient Track One ini berdasarkan Konsep Penataan Berbasis Komunitas. Secara umum konsep penataan berbasis komunitas ini terdiri atas lima target pengelolaan yaitu :

\subsubsection{Aspek Ekonomi}

Meningkatkan level ekonomi secara keseluruhan. Pencapaian aspek ekonomi terkait dengan peningkatan level ekonomi masyarakat memang merupakan tujuan utama dari pengembangan ancient track one ini. Level ekonomi masyarakat akan dikatakan meningkat bilamana telah terjadi perubahan seperti berkurangnya jumlah KK kurang mampu atau bahkan secara umum tingkatan ekonomi masyarakat mulai meningkat dari ekonomi lemah atau level ekonomi rendah menjadi tingkat ekonomi yang menengah.

Penciptaan lapangan pekerjaan. Pengelolaan ancient track one memang 
Tabel 4.1 Analisis CIPP (Context, Input, Process, Product) Ancient Track One

\begin{tabular}{|c|c|c|c|c|}
\hline $\begin{array}{c}\text { No } \\
1 .\end{array}$ & Aspek & Parameter & Indikator & Empirik (Hasil di Lapangan) \\
\hline & Context & $\begin{array}{c}\text { Tujuan } \\
\text { Pengembangan }\end{array}$ & $\begin{array}{c}\text { Aspek } \\
\text { Ekonomi }\end{array}$ & $\begin{array}{l}\text { - Meningkatkan level ekonomi secara } \\
\text { keseluruhan terhadap masvarakat. }\end{array}$ \\
\hline & & & & - Penciptaan lapangan pekerjaan. \\
\hline & & & & - Meningkatkan pendapatan masyarakat \\
\hline & & & Aspek & - Meningkatkan kualitas kehidupan sosial. \\
\hline & & & Sosial & \\
\hline & & & & - Meningkatkan rasa memiliki di masyarakat. \\
\hline & & & & - Keseimbangan sosial di masyarakat. \\
\hline & & & & - Memperkuat organisasi kemasyarakatan. \\
\hline & & & Aspek & - Promosi dengan dasar sikap toleransi. \\
\hline & & & $\mathrm{Bu}$ & \\
\hline & & & & - Pertukaran budaya. \\
\hline & & & & - Penguatan budaya lokal. \\
\hline
\end{tabular}

2. Input Daya Dukung Daya Tarik - Terdapat dua belas (12) potensi daya tarik. Informasi Informasi - sarana promosi an ancient track one. Personil SDM - Sebelas (11) orang pengelola.

Organisasi Pengelolaan - Keberadaan organisasi pengelola.

3. Process Perencanaan Perencanaan - Perencanaan teknis yang dilakukan oleh Potensi Disparda Gianyar menggunakan pola Top Down.

Pengorgani- Pengorgani- - Pengorganisasian kegiatan wisata. sasian sasian

Pelaksanaan Cakupan - Kegiatan ancient track one ini berupa wisata Kegiatan tracking

Pengawasan Monitoring - Pengawasan oleh masyarakat yang tinggal di Desa Wisata Bedulu dan Desa Buruan.

4. Product Hasil Pelayanan - Pelayanan terkait dengan penawaran produk Wisata wisata ini diharapkan lebih spesifik.

Jumlah - Hingga bulan April tahun 2016 sebanyak

Kunjungan 187 orang wisatawan yang berkunjung

Wisatawan (something to do).

Partisipasi - Masyarakat sangat antusias dan bersemangat Masyarakat dengan adanya program ancient track one.

Sumber: Hasil Penelitian, 2016

diharapkan akan memunculkan kegiatan ekonomi baru yang ada dan melekat di masyarakat. Peran dari warga masyarakat dalam bidang ekonomi berupa pekerjaan sebagai pedagang, bidang pekerjaan sebagai pengrajin, bidang pekerjaan sebagai guide, pekerjaan sebagai pengelola ancient track one atau kegiatan lain yang berhubungan dengan ancient track one.

Meningkatkan pendapatan masyarakat lokal. Peningkatan pendapatan merupakan sebuah ukuran kuantitatif terkait adanya perubahan pendapatan masyarakat akibat perubahan atau penambahan kegiatan ekonomi masyarakat. Diharapkan dalam program ini masyarakat masih menjalankan 
meningkatkan rasa memiliki di masyarakat sehingga masyarakat akan lebih bertanggung jawab untuk memelihara dan menjaga keberadaan, kebersihan dan kualitas seluruh sarana dan prasarana wilayah yang ada di ancient track one sesuai dengan konsep Community Based Tourism.

Kondisi ini didasarkan atas dua hal pokok yaitu masyarakat telah merasakan dampak yang besar dengan adanya ancient track one terkait dengan pengadaan dan peningkatan sarana dan prasarana umum di lingkungan mereka dan adanya kegiatan pariwisata yang menuntut kondisi yang baik dan bersih terkait keberadaan sarana dan prasarana umum tersebut.

Keseimbangan sosial dan peran di masyarakat. Pengembangan ancient track one dilakukan dengan peran masyarakat dan kelompok masyarakat selain peran pemerintah yang dalam hal ini dilakukan oleh Dinas Pariwisata Kabupaten Gianyar beserta pihak Desa Wisata Bedulu dan Desa Buruan. Masyarakat yang berada di sekitar ancient track one berperan aktif dalam proses perencanaan, pelaksanaan pelayanan wisata, dan pengawasan terkait dengan pengelolaan ancient track one sebagai sebuah daya tarik wisata. Maka dengan adanya peran masyarakat dan kelompok masyarakat, merupakan wujud keseimbangan peran sosial antara masyarakat, kelompok elite masyarakat dan pihak pemerintah.

Memperkuat partisipasi dari organisasi kemasyarakatan. Keberadaan organisasi kemasyarakatan yang ada disekitar ancient track one berupa organisasi subak sawah, subak kebun, sekhaa gong, sekhaa teruna teruni dan sejumlah kelompok usaha masyarakat seperti usaha pengerajin paras dan pengerajin ukir kayu. Sejumlah organisasi ini menjadi bagian dari paket wisata ancient track one dan terlibat secara langsung baik secara organisasi maupun secara keanggotaan.

Secara organisasi partisipasi dalam bentuk pengenalan organisasi baik dalam lingkup sentra kegiatan organisasi maupun hanya berupa papan nama organisasi saja yang menjadi penjelas dan penegas bahwa keberadaan organisasi tersebut benar adanya. Secara keanggotaan, dalam kegiatan wisata pada ancient track one diharapkan aggota organisasi secara alamiah melakukan rutinitas sebagai anggota masyarakat dan anggota organisasi yang dapat memperkuat citra daya tarik wisata ancient track one sebagai kawasan yang bercirikan cagar budaya dan budaya masyarakat itu sendiri.

\subsubsection{Aspek Budaya}

Promosi, toleransi dan saling menghargai terhadap wujud budaya yang berbeda. Keikutsertaan seluruh anggota masyarakat dan seluruh organisasi yang ada di masyarakat pada sekitar ancient track one menjadi sebuah sumber daya usaha yang sangat besar guna menumbuhkembangkan dan pengenalan wisata ancient track one kepada pihak luar (target pasar). Masyarakat dan organisasi masyarakat melakukan promosi terkait dengan 
keberadaan ancient track one dan sejumlah potensi wisata yang ada di Desa Wisata Bedulu dan Desa Buruan.

Keberadaan sejumlah potensi wisata yang ada di sekitar ancient track one memiliki karakteristik yang sangat berbeda baik dari unsur kepercayaan agama (terdapat situs Hindu dan Budha), kesejarahan yang berbeda (perbedaan jaman antara jaman pra sejarah hingga jaman kerajaan Bali kuno) menjadi sebuah bentuk toleransi yang disajikan bahwa pada ancient track one ini dapat dilihat keharmonisan terhadap wujud kebudayaan.

Pertukaran budaya. Proses pertukaran budaya diharapkan dapat meningkatkan keterbukaan pandangan dan pemikiran tentang kehidupan bermasyarakat dan teknologi hidup. Masyarakat akan menceritakan melalui guide atau pemandu wisata pada ancient track one terkait dengan budaya lokal, pada saat yang bersamaan wisatawan akan membandingkan apa yang dilihat pada ancient track one dengan daerah asalnya atau dengan pengetahuan (something to share) yang dimiliki.

Penguatan budaya lokal. Penguatan yang dimungkinkan yaitu meningkatnya kesadaran masyarakat akan berharganya budaya yang mereka miliki yang secara nyata sangat dihargai oleh wisatawan dengan datang dan berkunjung ke ancient track one. Masyarakat akan semakin menggali nilai dan ritual budaya yang mulai luntur guna proses pengenalan kembali kepada pihak luar terkait dengan budaya seperti apa yang mereka miliki.

\subsection{Aspek Input Pengembangan Ancient Track One}

Sebagai sebuah daya tarik wisata yang berbasis keberadaan cagar budaya, alam dan kehidupan masyarakat setempat, ancient track one membutuhkan masukan atau input untuk melakukan operasional dan pelayanan wisata kepada wisatawan. Aspek masukan atau Input yang didiskripsikan dalam sub bab ini lebih kepada unsur produk, unsur informasi, unsur sumber daya manusia, unsur pendanaan dan keberadaan organisasi pendukung (Husein, 2009). Seluruh unsur masukan ini dimanfaatkan guna mendukung pelayanan kegiatan wisata di ancient track one. Secara garis besar penjabaran mengenai unsur masukan atau Input dalam pengembangan ancient track one adalah :

\subsubsection{Unsur Potensi Daya Tarik.}

Mengacu kepada Dokumen Historical and Archaeological Guide To The Pakerisan and Petanu Rivers, dijabarkan bahwa potensi pariwisata yang ditawarkan (something to see) pada ancient track one ini berupa: Goa Gajah, Pura Dedari, Pura Jaksan, Pura Pengastulan, Pura Alit, Pura Dharma, Situs Sarkofagus, Yeh Pulu, Arca Ganesha, Pura Subak Kedangan, Pura Bukit dan Darma Durga Kutri. 
berada disepanjang Ancient Track One seperti Sekhaa Santi, Sekhaa Teruna, Sekhaa Cak, Pecalang, Sekhaa Gong, Sanggar Tari, dan Sekhaa Angklung.

\subsection{Aspek Process Pengembangan Ancient Track One}

Menindaklanjuti keberadaan sumber potensi wisata yang ada di Desa Wisata Bedulu dan Desa Buruan khususnya terkait dengan keberadaan Ancient Track One, Pemerintah Kabupaten Gianyar melalui Dinas Pariwisata Kabupaten Gianyar dan organisasi pengelola Ancient Track One melakukan sejumlah upaya pengelolaan tahap awal. Sejumlah upaya pengelolaan yang dilakukan meliputi :

\subsubsection{Perencanaan}

Dinas Pariwisata Kabupaten Gianyar melakukan perencanaan teknis terkait dengan wisata Ancient Track One yang nantinya akan dikembangkan sebagai sebuah produk wisata. Dinas Pariwisata merancang dua macam pada kawasan dari Goa Gajah hingga Puri Blahbatuh. Ditetapkan dua wisata yaitu Ancient Track One dan Ancient Track Two. Dalam perancangan wisata Ancient Track ditetapkan dua belas (12) daya tarik wisata pada Ancient Track One dan empat (4) daya tarik wisata pada Ancient Track Two. Proses perencanaan dilakukan dengan pola top down dimana pemerintah menentukan lokasi mana yang dipilih menjadi wisata yang menghubungkan sejumlah daya tarik wisata yang ada di sepanjang daerah Sungai Petanu dan Pakerisan.

\subsubsection{Pengorganisasian}

Menindaklanjuti proses perencanaan yang telah dilakukan oleh Dinas Pariwisata Kabupaten Gianyar, dilakukan sejumlah upaya untuk mengembangkan dan melakukan pengorganisasian terkait dengan apa yang ada di Desa Wisata Bedulu dan Desa Buruan yang dapat dikembangkan atau diorganisir sebagai pelaku pengelola daya tarik wisata Ancient Track One ini. Sebagai bentuk upaya pengorganisasian kegiatan wisata ini secara resmi Dinas Pariwisata sebagai pihak pencetus ide pengembangan daya tarik wisata ini belum menunjuk atau mengorganisasian lembaga.

\subsubsection{Pelaksanaan}

Pelaksanaan pelayanan wisata yang dilakukan mencakup kegiatan tracking menelusuri sejumlah lokasi daya tarik wisata pada Ancient Track One mulai dari start dari Goa Gajah hingga finish dilokasi Pura Bukit Darma Durga Kutri. Tidak banyak paket produk wisata yang disajikan atau ditawarkan ditempat ini. Pihak Dinas Pariwisata kabupaten Gianyar mulai mengembangkan wisata pendidikan (something to learn) dan kegiatan wisata religius khususnya pada sejumlah daya tarik wisata. Pada daerah Pura 
Bukit Dharma Durga Kutri telah mulai dikembangkan kegiatan pariwisata yang berbasis kegiatan wisata spiritual yang menyajikan yoga dan sejumlah kegiatan spiritual lainnya terutama pada sekitar areal pura.

\subsubsection{Pengawasan}

Kegiatan pengawasan lebih kepada bagaimana perilaku dan dampak kegiatan wisata oleh wisatawan, apakah telah sesuai dengan aturan dan norma yang berlaku di masyarakat. Secara khusus belum ditetapkan mekanisme teknis terkait dengan bagaimana pelaksanaan monitoring atau pengawasan kegiatan wisata yang ada. Masyarakat sebagai pemilih potensi wisata dan sejumlah organisasi

\subsection{Aspek Product Pengembangan Ancient Track One}

Penjabaran aspek produk merupakan keluaran dari apa yang sudah menjadi input dan proses pengelolaan input yang telah dilakukan. Secara teknis penjabaran aspek produk mencakup sejumlah hal yaitu :

4.4.1 Pelayanan wisata.

Pelayanan wisata dilakukan terkait dengan penawaran produk wisata, pengorganisasian tim dan bagaimana program pengembangan organisasi dan kegiatan wisata yang ada di sepanjang Ancient Track One. Penawaran produk wisata ini sasaran wisatawan yang diharapkan lebih spesifik sehingga membutuhkan usaha yang lebih kuat untuk mengembangkan pemasaran kepada target pasar. Penawaran produk wisata dua wisata ini dilakukan pada areal Goa Gajah sebagai lokasi start. Pengorganisasian tim dilakukan dengan mengefektifkan tim sebagai pengelola paket wisata yang telah ditetapkan sebagai produk wisata kepada wisatawan. Dengan jumlah tim sebanyak sebelas (11) orang, organisasi pelaksana telah melakukan upaya semaksimal mungkin untuk melakukan pelayanan wisata khususnya kepada wisatawan atau pihak lain yang ingin mengetahui dan menikmati paket wisata yang ditawarkan.

Organisasi pengelola belum memiliki legalitas sebagai lembaga pengelola tracking ini. Belum ditetapkan hak dan kewajiban dan kewenangan lembaga pengelola sebagai organisasi yang memanfaatkan dan mengelola sumber daya potensial pariwisata yang ada disepanjang ini. Pada awal perencanaan Ancient Track One sebagai sebuah daya tarik wisata, secara kontekstual tidak ada program pengembangan yang ditetapkan oleh Dinas Pariwisata Kabupaten Gianyar.

\subsubsection{Jumlah kunjungan wisatawan.}

Tingkat Kunjungan wisatawan dari bulan Januari hingga bulan April tahun 2016, ke wisata Ancient Track One ini adalah sejumlah 187 orang wisatawan. Jumlah ini sangatlah kecil bilamana dibandingkan dengan 
kunjungan wisata pada sejumlah data tarik wisata yang ada di sepanjang Ancient Track One ini. Pengukuran jumlah kunjungan wisatawan menjadi salah satu ukuran keberhasilan pengelolaan sebuah daya tarik wisata. Ukuran 187 orang wisatawan dinyatakan kurang memberikan nilai positif terkait dengan keberhasilan pengelolaan bilamana dibandingkan dengan pendapatan yang diperoleh dan dibandingkan dengan jumlah kunjungan wisatawan ke sejumlah potensi wisata tracking (something to do) yang berada di Ancient Track One.

Alline Marvella (20), wisatawan asal Perancis yang mengikuti kegiatan wisata traking Ancient Track One pada Januari 2016, memberikan keterangan tentang pengalamannya menyusuri Desa Wisata Bedulu dan Desa Buruan, Blahbatuh Gianyar sebagai berikut:

the activities of this tour is very fun and make me understand the beauty of nature, ancient relief, sacred statue, and stretch of rice fields in the village, I hope to visit again with friends or family in france. I hope the cleanliness and beauty in this village will always be maintained its authenticity. (Wawancara dengan wisatawan)

\subsubsection{Partisipasi masyarakat.}

Partsipasi masyarakat dapat dikatakan sangat tinggi dengan adanya kegiatan wisata ini. Masyarakat turut serta dalam pengelolaan dan pelayanan wisata meskipun tidak banyak anggota masyarakat yang terlibat dalam organisasi pengelola (hanya 11 orang).Tingginya partisipasi masyarakat menjadi sebuah tolak ukur keberhasilan program dimana saat ini masyarakat memiliki rasa kepercayaan diri yang tinggi bahwa kegiatan kebudayaan dan berkesenian yang ada dilingkungannya diapresiasi oleh pemerintah dan wisatawan.

\section{Simpulan}

Berdasarkan uraian di atas, dapat disimpulkan bahwa upaya pengembangannya, Ancient Track One memiliki penyimpangan atau ketidaksinkron aspek dalam rangka pengembangan sebagai sebuah daya tarik wisata alternatif. Penegasan aspek konteks yang mencakup aspek ekonomi, sosial, budaya, lingkungan, dan politik telah secara tegas digambarkan. Pada aspek input, unsur produk, sistem informasi, pendanaan, organisasi dan sumber daya manusia tidak dalam kondisi tersedia dan tercukupi.

Sebagai bagian dari aspek pengelolaan, unsur potensi daya tarik telah tersedia dengan ditetapkannya kegiatan wisata Ancient Track One sebagai jalur wisata, namun yang berfungsi dan menarik dalam kegiatannya ialah Ancient Track One. Tetapi aspek lainnya belum tersedia dan dapat dimanfaatkan guna pengembangan kepariwisataan di daerah ini. Aspek 
proses secara umum hanya pada tahap perencanaan dan pelaksanaan yang telah dilakukan.

Perencanaan telah dilakukan oleh Dinas Pariwisata Kabupaten Gianyar dengan menetapkan bahwa daerah ini merupakan sebuah alternatif kegiatan wisata baru di Gianyar. Sementara unsur pengorganisasian dan unsur pengawasan tidak dapat berlangsung secara optimal akibat belum ditetapkannya pembagian hak, kewajiban dan kewenangan para pihak yang akan dilihatkan dalam pengembangan jalur Ancient Track One. Aspek Product pada penelitian ini dijabarkan unsur pelayanan wisata, jumlah kunjungan, partisipasi dan multiflier effect. Produktifitas Aspek Product dirasakan kurang baik untuk jumlah kunjungan wisatawan, pelayanan wisata dan multiflier effect yang dirasakan oleh masyarakat. Untuk unsur partisipasi masyarakat relatif baik karena tingginya minat masyarakat untuk mengembangkan pariwisata di daerah ini baik dari sisi Desa Wisata Bedulu maupun Desa Buruan. Secara umum akibat kurangnya Aspek Input dan Process pengakibatkan unsur Product tidak dapat menghasilkan produk yang diharapkan.

\section{Ucapan Terima Kasih}

Pada kesempatan ini perkenankanlah penulis mengucapkan terima kasih yang sebesar-besarnya kepada Dr. Ir. Syamsul Alam Paturusi, MSP., pembimbing I yang dengan penuh perhatian telah mernberikan dorongan, semangat, bimbingan, dan saran selama penulis mengikuti program pascasarjana kajian pariwisata, khususnya dalam penyelesaian artikel jurnal ini. Terima kasih sebesar-besarnya pula penulis sampaikan kepada Dr. I Nyoman Sukma Arida, M.Si., Pembimbing II yang dengan penuh perhatian dan kesabaran telah memberikan bimbingan dan saran kepada penulis. Ungkapan terima kasih penulis sampaikan pula kepada para penguji Tesis, yaitu Prof. Dr. I Wayan Ardika, MA., Dr. Drs Nyoman Sunarta, M.Si., Dr. I Nyoman Sudiarta, SE., M.Par., yang telah memberikan masukan, saran, sanggahan, dan koreksi sehingga artikel jurnal ini dapat terwujud.

\section{Daftar Pustaka}

Graff, H.J. de \& Th. G. Pigeaud. 1985. Kerajaan-kerajaan Islam Hindu di Nusantara. Jakarata: Grafiti Pers.

Rencana Pembangunan Jangka Menengah Desa (RPJM Des) Tahun 2016-2022 Desa Buruan, Kecamatan Blahbatuh, Kabupaten Gianyar, Provinsi Bali

Sugiana, 2015. Program Ipteks Bagi Wilayah (IbW) Penataan Kawasan Situs Goa Gajah (dokumen). Kabupaten Gianyar: Universitas Warmadewa dan Universitas Dwijendra

Stufflebeam, D.L. 2003. The CIPP Model for Evaluation ,the Article Presented at the 2003 Annual Conference of the Oregon Program Evaluators Network (OPEN) 3 
Oktober 2003. Diambil pada tanggl 15 Januari 2016, dari http://www.wmich. edu/evalctr/cippmodel.

Undang-undang Republik Indonesia No. 10 Tahun 2009 Tentang Kepariwisataan Umar, Husein. (2008). Metode Riset. Jakarta: PT. Gramedia Pustaka Utama.

Profil Desa Bedulu, Kecamatan Blahabatuh, Kabupaten Gianyar, Provinsi Bali Tahun 2013/2014

Zhang, G. et. Al. 2011. "Using the Context, Input, Process, and Product Evaluation Model (CCIP) as a Comprehensive Framework To Guide the Planning Implementation, and Assessment of Service-learning Programs”. Journal of Higher Education Out Research and Engagement. Volume 15, number 4, p.5769.

\section{Profil Penulis}

I Gede Anom Sastrawan adalah Dosen Jurusan S1 Destinasi Pariwisata, Fakultas Pariwisata, Universitas Udayana. Ia menyelesaikan program S1 Destinasi Pariwisata pada Fakultas Pariwisata, Universitas Udayana pada tahun 2014 dan Program Magister Pariwisata di Pascasarjana Universitas Udayana tahun 2016. Saat ini mengabdi sebagai pengajar di Fakultas Pariwisata, Universitas Udayana, mengampu mata kuliah Pembiaayan Pembangunan Pariwisata, Aplikasi Komputer, Proses Perencanaan Pariwisata, Teknologi Informasi Pariwisata, Wisata Perkotaan dan Sistem Pariwisata Email: anom_sastrawan@unud.ac.id

Syamsul Alam Paturusi adalah Guru Besar Perancangan Kota pada Jurusan Arsitektur, Fakultas Teknik Unud dan dosen Prodi Magister Kajian Pariwisata, saat ini menjabat sebagai sekretaris program studi Magister Kajian Pariwisata, Universitas Udayana. Selain itu, beliau juga aktif mengajar sebagai dosen pada S1 dan S2 Teknik Arsitektur Unud; S3- Pariwisata, Unud; dan S2-S3 Ilmu Lingkungan, Unud. Sarjana (S1) di Arsitektur Universitas Hasanuddin, Makassar, jenjang Magister (S2) di PWK ITB, Bandung, dan jenjang Doktor ( $\mathrm{S}_{3}$ ) di Université de Pau et des Pays de l'Adour, Prancis. Email: syamsul_alam_paturusi@yahoo.fr

Nyoman Sukma Arida adalah dosen Prodi Magister Kajian Pariwisata dan Prodi S1 Destinasi Pariwisata. Ia aktif dalam aktivitas pendampingan masyarakat, riset dan penulisan. Pernah aktif di Yayasan Wisnu, Denpasar (2001), Yayasan Uluangkep (2004), dan Majalah Sarad (2001-2006). Di luar itu ia juga interes dengan isuisu lingkungan, pendidikan humanis, dan anak-anak. Beberapa publikasinya yang berupa buku, antara lain Mengelola Konflik Batas Wilayah Desa (2004), Remaja Bali di Dua Dunia (2005), Merentas Jalan Ekowisata Bali (2009) dan Sebuah Buku Kumpulan Tulisan Pariwisata Berkelanjutan dalam Pusaran Krisis Global (2010). Program pendidikan yang sudah ditempuh yaitu Sarjana (S1) di UGM (Yogjakarta), jenjang Magister (S2) di Pascasarjana Universitas Udayana, Denpasar dan jenjang Doktor (S3) di UGM. Email: sukmaarida@unud.ac.id 